DOI: $10.20472 / S S .2018 .7 .1 .001$

\title{
POSSIBLE EFFECTS OF UK'S SEPARATION FROM EU
}

\section{EKREM YASAR AKCAY}

\begin{abstract}
:
One of the major EU countries, the United Kingdom (UK), the EU has become a member after the first wave of enlargement. Historically Great Britain which opposed to the idea of a European Union, it has been in the economic and political interests despite efforts need to be a member of the Union. UK which became to member of EU, After UK's application was rejected twice by Former French President Charles De Gaulle, took up a position the attitude towards EU integration by avoiding the problems inherent in the EU up to now. Recently leading to a referendum on EU membership in the UK, $52 \%$ of the people have voted to leave the EU. As a result of this situation, Britain's status will be determined according to Lisbon Treaty article 50. In this context, after England's departure from the EU, both in the the Union and in the UK what kind of changes, the advantages and disadvantages are problem of our study. Thus, with the departure of the UK from the EU, an evaluation will be carried out in the same way that economic troubles can be experienced and similar problems can be experienced in the EU, such as the separatist movements and the disintegration of the EU. In this context, it is aimed that the UK will face economic difficulties and the EU will face the danger of dispersal.
\end{abstract}

\section{Keywords:}

EU, United Kingdom, Lisbon Treaty, Separation from the EU, Referendum.

JEL Classification: Z00, Z19

\section{Authors:}

EKREM YASAR AKCAY, Hakkari Universitesi, Turkey, Email: ey_akcay@hotmail.com

\section{Citation:}

EKREM YASAR AKCAY (2018). POSSIBLE EFFECTS OF UK'S SEPARATION FROM EU . International Journal of Social Sciences, Vol. VII(1), pp. 1-12., 10.20472/SS.2018.7.1.001 


\section{Introduction}

UK is the largest and most central of the four constituent countries that have brought about the United Kingdom (European Union, 2018). UK which had a routed history, has passed into the control of Denmark in the 11th century. After King Edward set up the Union in UK again, there has been Hundred Years' War between England and France. In 1707, the Acts of Union was signed among England and Scotland and was created Kingdom of Great Britain. Then in 1801, Ireland joined the United Kingdom of Great Britain (The Scotsman, 2018). In the 18th and 19th century England which has a big industrial state, has tried to improve the economy by establishing colonial government in several places.

UK which emerged victorious from the First World War, has been severely affected by the economic crisis in 1929. Although Britain emerged victorious from the Second World War, it has lost its status as süper power. After Second World War UK became member of some organisation such as NATO, United Nations (Lauderable, 2016). Firstly UK for economic and politic self-interests became a founder member of European Free Trade Agreement (EFTA) that was establihed as an alternative instead of European Economic Community (EEC). But UK tended towards EEC membership later because of economic problems and economic interests although UK opposed to European integration all along due to UK didn't want to a new power in Europe differ from UK and its economic and commercial gains. In the context of this idea, UK applied to EEC for EEC memebership twice in 1961 and 1967 but its applications was rejected by Former French President Charles De Gaulle because of interests of France and Europe. After De Gaulle resigned, UK became a member of EEC in 1973 with Ireland and Denmark (Preston, 1995).

Even if UK became a EU membership, it would have avoided from EU, its policies and bothers such as Schengen Area, Monetary policy, global economic crisis (Medrano, 2003). Because of this situation There are so many and different debates from each other about UK's separation from EU. A group thinks that could damage the UK's economic considerably while the other thinks that it would be advantageous for UK. Our study will examine what UK would be the case leaving from the EU. On the other hand, our study will examine how will be perceived in other countries of the UK's exit from the EU and will explore that improves the separatist movement, will make judgments about the future of the EU. However, with the separation of the UK from the EU, an evaluation will be carried out in the same way that economic troubles can be experienced and similar problems can be experienced in the EU, such as the separatist movements and the disintegration of the EU. Therefore, it will be shown in this study that the EU might face the danger of dispersal, as the UK will have problems economically with the emergence of the European Union and the European Union will be exposed to separatist movements. Primarily, the study will examine the UK's membership to the EU. Then the Brexit process will be discussed and finally the Brexit process will be evaluated on the possible positive and negative effects of both the UK and the EU. In this way, both Brexit and similar initiatives will have knowledge of what the effects and what needs to be done. Because some of the evaluations that have been made suggest 
that the UK will have a serious economic crisis due to its separation from the EU, there is a debate about whether such separatist movements in the EU will cause breaks in the EU and even lead to the breakdown of the EU. With this study, it will be given an answer to this discussion. However, this work will benefit from the official sources of the European Union, as well as secondary sources such as books, articles and internet sources.

\section{UK's EU Membership Process}

After World War II, starting with the European Coal and Steel Community, Maastricht the role of the United Kingdom in the process of reaching the EU is always important (Sezgin, 2016). UK, throughout history, didn't look at to an integration that will founded in Europe seriously. Because both it doesn't consider such an integration could be achieved and doesn't want the presence of another power in continental Europe differ from it. The United Kingdom originally formed a structure by meeting with Commonwealth countries instead of this structure in Europe. In other words UK designed to make Free Trade Agreement with EU initially and was signed Stockholm Agreement European Free Trade Agreement (EFTA) was established (Ferrera, 2002).

Within the EFTA Commonwealth countries are important for both commercial and foreign policy in UK. Commonwealth countries, has a share of 43 percent in British trade (Akçay, Akman and Akman, 2012). But the basic situation in here is that UK makes cheap agricultural policy with the Commonwealth countries. In this sense, when look at to Continental Europe, the Common Agricultural Policy, is a policy that is under the influence of France, and more expensive than Britain's Commonwealth policy. Because of expensiveness of Europe Common Agricultural Policy and scarcity of agricultural land in UK, and therefore the fact that UK will receive less money from Europe, than it pays, Britain was not hot to the issue, it has created hesitation. Because this policy will create a deficit on the balance of payments in UK. On the other hand The Former French President Charles De Gaulle has opposed to UK's membership due to some justifications such as having the economic downturn of UK and depending on the economically and diplomatically of UK to USA. The membership application in 1961 was rejected by Former French President Chales De Gaulle by claiming addiction UK's difficulties and closer relations with US After second application to EU was rejected again with the same grounds by De Gaulle in 1967, French President changed and in 1973 EU's doors opened to UK. However, deteriorating relations with Commonwealth countries of UK in time led it to the EEC (Grant, 2016). In fact, although United Kingdom wasn't hot for EEC membership, it wanted to make a Free Trade Agreement with the EEC and thus close the trade deficit by continuing relations with the countries of the Commonwealth. While UK was trying to establish a relationship with the EEC, on the other hand, it tried to continue its relationship with countries of the Commonwealth. One of the important reasons of this is for this is Sterling Area. Sterlin Area is so important for UK both commercially and financially. UK uses Sterling in trade with Commonwealth countries and also uses excess of the sterling appears in the Commonwealth countries as a result of being deposited to London banks, in the banking system and tries to eliminate trade deficit (Scott, 1959). 


\section{The Idea of UK's Separation From EU: Brexit ${ }^{1}$ Process}

Since 1973 UK which is member of the European Union, governments which came to office have no time to think on behalf of a referendum to leave the European Union. They always chose to protect of national interests in the European Union and turn in their favor. However, in changing of this view has been effective the some major factors. The first of these is that The Conservative Party which is power for two years, shows an anti-European stance (IKV, 2016). Second, and more important one is crises in the euro area (European Union, 2018). Thirdly EU evolved into a federal structure therefore it suggests to be increasingly difficult that EU institutions will reform about strengthening the sovereignty of member state. Therefore, being outside the Union, UK will be reclaimed its interdependence. Forthly it is claimed that EU market will not provide more benefit to UK according to supporting separation from EU. In this context if UK can start watching autonomous foreign trade policy, through more aggressive free trade agreements that have acquired the ability to reach more markets. The last one, UK, when it leaves the membership will be freed from the burden of his net contribution to the EU budget. Britain's net contribution to GDP in the period 2014-2020 is 0.5 per cent per year to the EU budget. In other words, While Britain's net contribution to the budget provided 11,3 billion pounds in 2014 and in 2017 reached 12,2 billion pounds (Black, Hall, Cox, et all, 2017)

The 'Brexit' referendum has been the main shaping of recent discussions in UK politics. The parties, which formed different colors of British politics, tried to persuade their people according to their position on 'Brexit'. Leaders of the Conservative Party and Prime Minister David Cameron were among those who campaigned to stay in the Union (Aran, 2017). In an announcement in 2013, Cameron said that in the event of their sole power, Britain would renegotiate the status within the EU, and that it would hold a referendum on the issue, depending on the conclusions it obtained. When the British people were surprised by the survey companies in 2015, bringing the Conservatives to power alone in general elections, Cameron also had the time to fulfill the commitment in 2013. Cameron has also made a strong deal with EU leaders in Brussels with his promise. As a result of the negotiations, it was announced that the basic issues that Cameron was sensitive were agreed upon (Cameron, 2018).

Counter-arguments by the said grounds are not based on solid foundation. First, Britain's political integration with EU, has reached a level that makes it practically impossible to live a break. Furthermore, according to this approach, the "independence" argument in the real world politically Britain's politics will mean it is less effective. So UK will have become "independent" but less effective actor. Second, according to the proEU approach the argument that leaving the EU will bring further trade liberalization is controversial. According to the findings of the Center for European Reform research institute, 50 percent of foreign direct investment stock in the UK it is of EU origin. Similarly, the presence of British banks in the euro zone is more than 70 percent of their assets in the US. In the field of trade EU is the UK's largest shareholder with a 50

\footnotetext{
${ }^{1}$ It is a Word that has used as a shorthand way of saying words Britain and Exit.
} 
percent share (Webb and Keep, 2016). Therefore, even if disconnected from the EU in order to keep open the UK's main markets continue to negotiate with the EU, but it must do without being EU member (Kutlay, 2016).

UK Prime Minister David Cameron's Conservative Party came to power in May 2015 elections and said that it would take the country in a referendum on EU membership by the end of 2017 (Mattjis, 2013). United Kingdom's exit from the EU, it's the possibility of a domino effect among European countries (Wheeler and Hunt, 2016). It is reported that this decision may trigger a similar EU referendum especially love the right to be popular in France. After Brexit decision that has been reported European Council, it will start a 2-year negotiation process to come together. In February 2016 leaving the issue of the EU with Britain's Cameron to give a date for the referendum on June 23, 2016 came back on the agenda. Cameron's decision is based on the 50th article of the Lisbon Treaty is supposed to report to the Council (Official Journal of the European Union, 2018). The process will begin this statement is made and the parties to negotiate an agreement that will allow the separation. From the moment that this agreement provided EU agreements will cease to be applied to the UK within two years at the latest. This time the possibility of extension, the US and the UK will only be possible with the unanimous (Miller and Lang, 2016).

\section{Possible Effects of the UK's Separation From The EU}

There are some discussion that Britain's separation from EU with result of plebiscite decision will mean the collapse of EU reverie. Britain's decision to leave the EU in terms of both the EU and the UK has begun a period of turbulence where the uncertainty is intense. Britain's decision to split is one of the most important breakpoints in EU history. Because Britain has the greatest military power of the EU, the second largest economy and the largest financial center. London, which is the center of the global financial system, will be significantly affected by this ambiguity. This is expected to push the global economy to seek a new financial system structure by raising criticism of the global financial system, which began with the global economic crisis of 2008 and accelerated with Panamanian documents. With the separation decision, London lost its position as the most important financial center of the world and the importance of finance centers like Frankfurt and Dublin further increase will be against UK (Koç, 2016).

In addition, from the point of view of enlargement policies, it should be noted that Britain has formed the face of globalization in the face of globalization. For this reason, the breakup of an important force like the United Kingdom from the EU will mean a loss of power in terms of unity. On the other hand, the EU is also the most important economic actor for the UK. Because $50 \%$ of the foreign direct investment stock in the UK is EU origin. The assets of the UK banks in the euro zone are 70 percent more than their assets in the US. Likewise, Britain makes 45 percent of its exports to the EU and 53 percent of its imports from the EU (Jensen and Snaith, 2016). But the global economic crisis has caused serious impacts in Europe and the EU. This has both shaken the image of the EU and strengthened the United Kingdom's decision to separate from the EU. After 2009 global economic crisis and economic and social developments, the 
European Union's political unity was the most important development of the ideal of gold discharges. Giving up their sovereignty in many areas of the sovereignity countries in deep crisis as 2009 global economic crisis has caused backlash. The Sun Newspaper in Britain indicated its first paper in the shape of geting rid of the Brussels diktat (The Sun, 2016). This situation is the most important grounds on which the EU supports the idea of leaving. In particular, some countries such as Greece, Spain, Portugal, Italy in the Mediterranean region has developed a nationalist vein rising unemployment and the huge revenue losses because of implications of economic crisis as economic saving. In terms of the UK Labor flow from unemployment to peak his country has overwhelmed the British people. The foreign-born people living in Britain, the proportion of the population in 2011 shows that 13.4 per cent rise in 2017 it became 34 per cent (Office for National Statistics, 2017).

Despite this, it is very obvious that damaged the British economy. It is estimated that The British pound against the US dollar could give up to $15 \%$ a derating. British Treasury prepared and issued a report in April; incase of Brexit, 15 years later Britain's national income will be 6.2 percent lower than a place (Office for National Statistics, 2016). Within the Brexit unable to find out the economic impasse, the EU's banking system collapsed politically attract the rope of hope in one stop. Flourishing in the Member States to provide power to the current racist and anti-EU. So EU will be instability both economic and politics. The European Council President Donald Tusk has done more scary estimated losses due to the long-term effects; As a historian said that not only the $\mathrm{EU}$, but also the fact that I'm worried about the beginning of the destruction of western civilization in its entirety

However In case of the union of UK, "freedom of movement" will emerge as the most important issue. Although UK actually seem disturbed many immigrants, the arrival of free movement provides a great benefit economically UK. Britain's freedom of travel within the EU chooses to leave the EU if the citizens of the country will become a controversial issue. According to United Nations data, in the first half of 2017 is estimated 4.7 million British citizens lived in other EU countries (United Nations, 2016).

On the other hand according to Global Councel report UK has constituted on sixth of European economy. One tenth of the EU's total exports has gone to the UK. Due to the different customs fees of UK's departure from the Union, not only the British economy at the same time exporting goods and products that are expected to affect the EU countries (Global Counsel, 2017). Similarly The EU will be geographically reduced by $250,000 \mathrm{~km} 2$, population by 65 million and economic output by 2.233 trillion euros (Boyraz, 2016).

According to the UK Office for National Statistics data, Europe is becoming a market for British exporters to decrease the share of the pie. 60 per cent of Britain's total exports to the EU in 2000, while this ratio to 58 percent in 2005 to 54 percent in 2010 and fell to 43 percent in 2017. UK's imports from the EU during the period 2000-2015 remained 54 percent level. Analysts foresee the case of UK's departure from the EU could suffer a loss of about 15-20 per cent of the value of the British pound. Present the results of some survey companies in the UK, separation is enough to put pressure on sterling and 
volatility even appear a few points ahead of bias. Central Bank growth forecast for this year from 2.2 percent to 2 percent, 2,4 percent for 2017 to 2.3 percent, from 2.5 percent in 2018, dropped to 2.3 percent. The Institute for Fiscal Studies (IFS) statement in the case of UK's departure from the EU, has warned could be forced to implement some of the new austerity measures for two years (Office for National Statistics, 2016). To cope with shocks that may occur after the UK's Brexit recorded statement some new cuts of implementation or may feel the need to continue increasing the existing cuts, the separation from the EU, the United Kingdom, 2019-2020 period until the public finances will be a cost of between 20 and 40 billion pounds specified (The Guardian, 2016). IMF Managing Director Christine Lagarde, the case of UK's departure from the EU's external financing may lose substantial value due to a sharp decline in the pound, it would be a large contraction in consumption and investment (Independent, 2016). Britain's leaving from the EU would constitute "the uncertainty" that could continue until the end of 2018, were recorded in this situation could lead to the reduction of investor confidence and investment. The reporthas been also advocated that can be reduced to 3 percent of the country's economic growth in 2020 if they remain outside the UK and the EU. However some think-tanks as Open Europe in the UK, Britain's departure from the EU and the open borders of the country to hold an annual cost of about 56 billion pounds by 2030 (84 billion dollars), it said that it would find (Regents University, 2018). Published by Open Europe and UK that would occur if the separation on January 1, 2018 the EU report which handles case scenario, the UK's Gross Domestic Product has drawn attention to UK separation may be less than 2.2 percent of the normal case (Open Europe, 2016b). In the report, Britain should leave from the EU agreement about border and trade arrangements, the total financial loss was reported between the years 20182030 the British economy will be able to find 672 billion pounds (Open Europe, 2016b). According to Stephen Tindale who is expert of The European Reform Center indicated that this plan will prevent a large number of foreign background may occur because it is difficult to implement such as different standards and regulations Therefore, some products duty-free trade in Europe can not be done as it is today (Druol, 2015).

However in the massacre of ISIS attacks with the European dimension of Syrian refugees stream, it raised the vessel with fear. Britain's decision to exit from the EU will lead to many political and economic consequences for both the EU, UK and also USA. It has encouraged to separatists in Scotland again that was rejected independence demand in a referendum last year. There is talk of a new referendum so that Scotland who want to stay in the EU. However it is close to being heard similar sounds in Northern Ireland. Brexit decision can inflame the issue of Ireland again. On the other hand We can expect a separatist movement in continental Europe may rise in the coming days (The Atlantic, 2016).

Therefore It can be predicted that the separation of the UK from the EU will also have a significant impact on the European integration. It would not be wrong to state that the first effect of the 'Brexit' decision is psychological. Because after the referendum, the dominant rhetoric in the EU shifted to the axis of 'dissolution' rapidly from the axis of 
'integration' which was the dominant theme of previous periods (Sampson, 2017). Because the EU member states will try to manage the output of the UK with the least damage from this point on the one hand and the domino effect on the other that will cause the breakdown to be resolved for the EU as a precedent for other countries to prevent it from creating. Britain's separation from the EUThe impact on European integration will be shaped by the degree of faithfulness of European leaders to the political horizon and the European integration Project (Vollaard, 2014).

\section{Conclussion}

UK-EU relations will continue to be a problem area. As long as it remains within the Union, the UK will continue to resist the federal European project. In case of separation of UK from EU, although it will lead to significant losses for the two sides the main loser will be the UK. Because UK will try to execute the non-union intense and arduous negotiation process in order to maintain their privileges gained. However, in this case, the UK which will be one of Europe's largest countries, will continue to be an actor of the European Project that can not be neglected. On the other hand even if UK separated from EU, because of global World and economic integration process, trade relations with two side will continue. There are alternative scenarios about this subject (Global Counsel, 2016).

On the other hand there are different scenarios for European Union and European Integration. The first scenario in which the UK is likely to emerge as a result of the separation is disintegrated. The loss of a large member may lead to a reversal of the EU integration process. Especially in continental Europe, it is envisaged that antiEuropean projects in the case of racist and xenophobic parties will try to pass on life, emphasize anti-immigrant policy, and prioritize protectionist economic policies. Following the referendum in Britain, the follow-up to referendum demands in France, the Netherlands, Denmark, Germany and Sweden strengthens the thesis of 'domino effect'. However, it is necessary to take a more cautious approach to the 'domino effect' argument if it is taken into account that the parties demanding separation in each country are not likely to come to power alone, at least not yet, and that the mainstream parties in these countries have EU pro-politics (Mazower, 2015).

The second scenario for the future of the EU is deeply integrated. In this scenario, however, a comprehensive reform / restructuring process will be required to be lifted in a short period of time in order to remove the structural constraints that cause the asymmetry of the EU's economic and political integration process. Because all the acute problems that the EU faces are directly related to the 'clumsy institutional governance' of the Union, especially the Euro depreciation and the crisis of migration. Solutions to these structural problems include eliminating the inconsistency between monetary and fiscal policies, transitioning to a federal governance system in the areas of migration, security and foreign policy, preconditions for the realization of this scenario. At the same time, the political and legal dimension of the economy, which is a federal EU, is the foreground of the passing of this scenario. This scenario is a counter-optimal solution in 
order to be able to effectively deal with problems that are but it is seen as the most difficult solution proposal to apply politically (Kutlay, 2013).

The third scenario is a differentiated integration scenario. According to this model, the European integration, which will be restructured into the circles of the interior rather than all the EU member states entering the same level and deep integration in every area, can be a structure in which integration with other areas over time is made flexible and this structure is a legal structure. the narrow "central group" will be closer to the federal European ideal in this respect, and many powers in the nation-state control will be carried to supranational level. Again, within the framework of the same architectural structure, the EU will become an intergovernmental body in terms of members who are outside of the integration process. At this point, differentiated integration can lead to an architecture in which some countries can concentrate more deeply on integration, while others can concentrate on areas they wish to be part of less sovereignty (Moravcsik, 1993).

Although it is seen as the third most advantageous scenario from this scenario, the European Union has begun to turn into a structure in which extreme right-wing parties start to come to power, especially with the influence of immigration policy and the global crisis. These new governments, operating on an anti-immigration policy and planning to leave the EU in the period of sovereignty, are pushing the Union to the future. Moreover, the European Union has not developed a policy against these events. For this reason it is likely that new divisions will be experienced following a division like Brexit and the EU will face the danger of disintegration. Because in the European Union countries, the right-wing parties have started to increase their voting rates and become stronger, leading to new developments within the EU. In 1999, the Freedom Party (FPÖ) led by Jörg Haider in Austria won $26 \%$ of the elections. In Denmark, the Danish People's Party had $23 \%$ of the vote. Nevertheless, racist parties have risen in the European Parliament elections held on 22-25 May 2017. The National Front, which represents extreme right in France, has been the winner of the European Parliament elections. Marie Le Pen's leadership has won $25 \%$ of the vote. The vote of the Socialist Party has fallen to $14 \%$. Because most Europeans have a serious frustration with the European Union because of the negativity of their governments' politics. For this reason, EU citizens have sought out differently and found the statements of the far right parties closer to them. This situation in the European Union countries has led to debates about the difficult times in the EU. Extreme right-wing parties, which have won support from the public by acting like rhetoric, anti-immigration, anti-Muslim, and unemployment, have begun to distort the system of values and values within the European Union. For the purposes of the Treaty of Lisbon, the European Union is a union based on fundamental human rights and also attaches importance to social rights. According to the second article of the Treaty, the principles of human dignity, freedom, democracy, equality, the rule of law, respect for human rights, pluralism, multiculturalism, tolerance, justice, solidarity and discrimination are common values of the EU.

In this context, it is difficult for the extreme right parties, which oppose the EU values and make it a policy to leave the EU, to increase the votes and strength of the people 
by the support of the people and to continue the EU as a whole. This is because, as far right parties increase their voting rates, the national democracy and the EU, which are considered important for these parties, appear to be two incompatible elements. Moreover, the extremist right-wing parties regard the EU as a deteriorated structure and argued that it would be better for them to get out of this structure. For example, the FPÖ in Austria believed that the national values of the states should be superior to those of the EU, while Austria is concerned about the protection of its homeland and national identity and values for the protection of Austria. For this, he suggested that Austria would be more advantageous if it emerged from the EU. In this case it will increase the likelihood of resurgence in Europe and the possibility of Europe entering an unstable process. Because the strengths and rhetoric of extremist right-wing parties will help support cracks, democratic corruption and violence in the country's internal politics. This is because raising the voting rates of extremist parties in Europe has led to an increase in nationalism in Europe. This strengthens exclusion and separation, not in Europe and in the EU. Britain's decision to abstain from the EU for the first time in its history. Moreover, this situation is on the agenda of extreme right parties in states like Holland and France. Such separatist ideals will both prevent the EU from becoming a global actor and lead to the damage of a structure like the EU.

\section{References}

AKCAY, E. Y., Akman, E. and Akman, C. (2012). The Eu Integration And The Monetary Union: Why England Don't Join The Euro. 3 rd International Symposium on Sustainable Development. Sarajevo, p. 268-272.

ARAN, B. (2017). Brexit Ve Küresel Ticarete Yansımaları. TEPAV Değerlendirme Notu. 201708, 1-8. BLACK, J., HALL, A., COX, K. (2017). Defence and Security after Brexit. California: Rand Publishing. BOYRAZ, H. M. (2016). Brexit: Birleşik Krallık Avrupa Birliği'nden Ayrılıyor mu?. SETA Perspektif. 134, p. 1-7.

CAMERON, D. (2018). UK's Cameron Speaks on EU Membership. Bloomberg. 23 January 2013.

DRUOL, E. M. (2015). The UK's EU Vote: The 1975 Precedent and Today's Negotiations. Bruegel Policy Contribution. 8, p. 1-10.

EUROPEAN UNION. (2018). United Kingdom. https://europa.eu/european-union/abouteu/countries/member-countries/unitedkingdom en.

FERRERA, M., MATSAGANIS, M. and SACCHI, S. (2002). Open Coordinations against poverty: The new EU Social Inclusion Process. Journal of European Social Policy. 12 (3), p. 1-24. https://doi.org/10.1177/0952872002012003396

GLOBAL COUNSEL. (2017). Brexit: The Impact on the UK and the EU. https://www.globalcounsel.co.uk/sites/default/files/specialreports/downloads/Global\%20Counsel Impact of Brexit.p df.

GRANDT, C. (2016). Why is Britain Euroscepcit?. https://www.cer.org.uk/sites/default/files/publications/attachments/pdf/2011/essay eurosceptic 1 9dec08-1345.pdf.

IKV. (2016). Britanya Referandumu Ve Sonrası: AB Entegrasyon Sürecinin Geleceği Ve Türkiye. IKV Raporu. 284, p. 1-48.

INDEPENDENT (2016). IMF Warns of substantial Economic Damage From Brexit. http://www.independent.co.uk/news/uk/politics/imf-warns-of-substantial-economic-damage-frombrexit-a7027331.html. 
JENSEN, M. D. and SNAITH, H. (2016). When Politics Prevails: The Political Economy of a Brexit. Journal of European Public Policy. 23(9), p. 1302-1310. https://doi.org/10.1080/13501763.2016.1174531

KOÇ, Y. E. (2016). Brexit Süreci, Küresel Ekonomi ve Türkiye: Fırsatlar ve Tehditler. SETA Perspektif. 135, p. 1-5.

KUTLAY, M. (2013). Euro Krizinin Politik Ekonomisi ve AB'nin Uluslararası Sistemdeki Geleceği. Fikret Şenses, Ziya Öniş ve Caner Bakır (eds.). Ülke Deneyimleri Işığında Küresel Kriz ve Yeni Ekonomi Düzen. İstanbul: İletişim Yayınları, p. 169-185.

(2016). Ingiltere AB'den Ayrılırsa Ne Olur?. http://www.usak.org.tr/tr/koseyazilari/ingiltere-ab-den-ayrilirsa-ne-olur.

LAUDERDALE, B. (2016). A Brief Political History of the United Kingdom. http://fivethirtyeight.com/features/a-brief-political-history-of-the-united-kingdom/.

MATTJIS, M. (2013). David Cameron's Dangerous Game: The Folly of Flirting with an EU Exit. Foreign Affairs. 10, p. 10.

MAZOWER, M. (2015). Karanlık Kıta: Avrupa'nın 20. Yüzyılı. İstanbul: Alfa Yayıncılık

MEDRANO, J. D. (2003). Framing Europe: Attitutes to European Integration in Germany, Spain and the United Kingdom, Princeton: Princeton University Press.

MILLER, V. and LANG, A. (2016). Brexit: How does the Article 50 process work. House of Commons Library Briefing Paper. 7551, p. 30-31.

MORAVCSIK, A. (1993). Preferences and Power in the European Community: A Liberal Intergovernmentalist Approach. Journal of Common Market Studies, 31 (4), p.473-524. https://doi.org/10.1111/j.1468-5965.1993.tb00477.x

OFFICE FOR NATIONAL STATISTICS (2017). How Important is The European Union to UK Trade and Investment. http://webarchive.nationalarchives.gov.uk/20160105160709/http://www.ons.gov.uk/ons/rel/interna tional-transactions/outward-foreign-affiliates-statistics/how-important-is-the-european-union-touk-trade-and-investment-/sty-eu.html.

OFFICIAL JOURNAL OF THE EUROPEAN UNION. (2018). Lisbon Treaty Article 50. http://eurlex.europa.eu/legal-content/EN/TXT/?uri=celex\%3A12007L\%2FTXT.

OPEN EUROPE (2016a). What if..? The consequences, challenges and opportunities facing Britain outside the EU. http://openeurope.org.uk/intelligence/britain-and-the-eu/what-if-there-were-abrexit/.

Wales in 2011.

(2016b). Immigration Patterns of Non-UK Born Populations in England and

http://webarchive.nationalarchives.gov.uk/20160105160709/http://www.ons.gov.uk/ons/dcp17177 6 346219.pdf.

PRESTON, C. (1995). Obstacles to EU Enlargement: The Classical Community Method and the Prospects for a Wider Europe. Journal of Common Market Studies. 33 (3), p. 453-461. https://doi.org/10.1111/j.1468-5965.1995.tb00543.x

REGENTS UNIVERSITY. (2018). The UK\&Europe: Costs, Benefits, Options. The Regents Report, 2013, http://www.regents.ac.uk/files/regentsreport2013.pdf.

SAMPSON, T. (2017). Brexit: The Economics of International Disintegration. Journal of Economic Perspectives. 31 (4), p. 163-184. https://doi.org/10.1257/jep.31.4.163

SCOTT, M. (1959). What Should Be Done About The Sterlin Area?. Oxford Bulletin of Economics and Statistics. 21 (4), p. 213-251. 
SEZGiN, C. (2016). Brexit: Birleşik Krallık'ın Avrupa Birliği'ndeki Geleceği mi?. Bilgesam Analiz. 1308, p. 1-8.

THE ATLANTIC (2016). Can Terrorists Really Infiltrate the Syrian Refugee Program?. http://www.theatlantic.com/politics/archive/2015/11/can-terrorists-really-infiltrate-the-syrianrefugee-program/416475/.

THE GUARDIAN (2016). World Trade Organisation adds new warning on economic cost of Brexit. http://www.warringtonguardian.co.uk/news/14513766. World Trade Organisation adds new war ning on economic cost of Brexit/.

THE SCOTSMAN. (2018). Scottish independence 'within next decade' - poll. http://www.scotsman.com/news/politics/scottish-independence-within-next-decade-poll-1$\underline{3775405}$.

THE SUN (2016). We urge our readers to beleave in Britain and vote to quit the EU on June 23. https://www.thesun.co.uk/news/1277920/we-urge-our-readers-to-believe-in-britain-and-vote-toleave-the-eu-in-referendum-on-june-23/.

UNITED NATIONS (2016). International Migration Report 2015. http://www.un.org/en/development/desa/population/migration/publications/migrationreport/docs/M igrationReport2015 Highlights.pdf.

VOLLAARD, H. (2014). Explaining European Disintegration. Journal of Common Market Studies. 52 (5), p. $1142-1159$. https://doi.org/10.1111/jcms.12132

WEBB, D. and KEEP, M. (2016). In Brief: UK_EU Economic Relations. Brief Paper. 06091, p. 1-20.

WHEELER, B. and HUNT, A. (2016). Brexit: All you need to know about the UK leaving the EU. http://www.bbc.com/news/uk-politics-32810887. 